\title{
Brazilian pine diameter at breast height and growth in mixed Ombrophilous forest in Southern Brazil
}

\author{
André Felipe Hess ${ }^{1}{ }^{*}$, Myrcia Minatti ${ }^{2}$, Veraldo Liesenberg ${ }^{1}$, Patrícia Povoa de Mattos ${ }^{3}$, Evaldo Muñoz Braz ${ }^{3}$, \\ Emanuel Arnoni Costa ${ }^{4}$
}

\author{
${ }^{1}$ Department of Forest Engineering, College of Agriculture and Veterinary (CAV), Santa Catarina State University \\ (UDESC), Luiz de Camoes Ave., 2090, Lages, Santa Catarina, Brazil \\ ${ }^{2}$ Department of Forest Engineering, Federal University of Paraná (UFPR), Pref. Lothario Meissner Ave., 900, Curitiba, \\ Paraná, Brazil \\ ${ }^{3}$ EMBRAPA Forestry, Ribeira Road, km 111, P.O. Box 319, Colombo, Paraná, Brazil \\ ${ }^{4}$ Forest Engineering, Department of Forest Engineering, Federal University of Santa Maria, 1000 Roraima Ave., \\ 97105-900, Santa Maria, Rio Grande do Sul, Brazil
}

*Corresponding Author: hessandre@yahoo.com.br

\begin{abstract}
Information on the diameter at the breast height (DBH) growth of trees can be useful to understand their productivity and temporal dynamics in natural forests. This study presents the first results of increments in DBH of Araucaria angustifolia trees since their logging prohibition in southern Brazil, in late 1970s. We used dendrochronology techniques in 210 individuals in three different sites, which allowed a retrospective analysis of the DBH increment from 60 to 150 years. We adjusted temporal dimensional models whose results may help to support a sustainable forest management of $A$. angustifolia in southern Brazil. The results showed that the width of annual growth rings varied from 0.04 to $4.8 \mathrm{~cm}_{\text {year }}{ }^{-1}$ along the last 60 to 150 years, and the mean annual increment ranged from 0.3 to $0.9 \mathrm{~cm}_{\text {year }}{ }^{-1}$. The DBH increment accumulated in the last ten years showed a decreasing pattern, indicating that most of the sampled trees had already reached maturity. This result denotes a proportional loss in DBH increment with increasing DBH and age. Decreasing DBH growth rates became even more evident in the last ten years (i.e. $\sim 0.15$ $\mathrm{cm}$ year ${ }^{-1}$ ), indicating a need of silvicultural intervention in some sites to reduce competition among trees for soil nutrients and light. Regarding the average DBH increment growth, the time the trees need to reach the optimal DBH harvesting diameter of 40 $\mathrm{cm}$ ranged from 25 to 112 years, according to the local site index characteristics. The curve inflection point that represents the DBH increment occurred between 35 and 45 years for this specific DBH. These results confirm the viability and need of forest management practices of $A$. angustifolia trees due to the saturation of the trees DBH growth and increment capacity that reached its inflection. Therefore, since their logging prohibition, most $A$. angustifolia trees reached their optimal DBH harvesting size. Forest management is necessary for conservation of the forest structure. It would favor the growth of young A. angustifolia, seedling productions, the natural regeneration of this species and genetic diversity; and stimulate the increase of timber production.
\end{abstract}

Keywords: DBH growth model; diametric growth; Araucaria angustifolia; Atlantic Rain Forest; technical rotation.

Abbreviations: DBH_diameter at breast height; MOF_Mixed Ombrophilous Forest; id_annual increment in diameter; $M C D$ _ minimum cutting diameter.

\section{Introduction}

The Atlantic Rain Forest is one of the largest humid tropical forests of the Americas. The Mixed Ombrophilous Forest (MOF), located in the southern part of the Atlantic Forest biome, is characterized by the presence of Araucaria angustifolia (Bertol.) Kuntze trees. It is also known as Brazilian pine. Natural areas of $A$. angustifolia occupied originally $200,807 \mathrm{sq}$. $\mathrm{km}$ in southern Brazil, $40,807 \mathrm{sq}$. $\mathrm{km}$ in the State of Santa Catarina (Klein, 1978). It is one of the most important tree species in southern Brazil because it generates high-value wood prodicts and has a cultural significance (Silveira, 2005).
The MOF occupies approximately $12 \%$ of its original area (Ribeiro et al., 2009). Several other tree arboreous species are usually predominant below its canopy strata, especially Myrtaceae and Lauraceae, and a high density of arborescent pteridophytes (Dicksonia sellowiana and Alsophylla sp.) and bamboos (Merostachys spp.) (Nascimento et al., 2001).

In the early 1900s, large areas of Brazilian pine forests were intensively exploited due to the commercial value of the Brazilian pine timber, and for extraction of its edible seeds (Oliveira et al., 2009, Mattos et al., 2011). The Brazilian federal government prohibited timber exploitation and any forest management practice on this species in the 
late 1970s (Hess et al., 2009; Diez, 2012). Thus, the lack of information on the growth of forests with Brazilian pine and the resilience of this species also contributed to the reduction, stagnation, and low diversity of the natural remnants of these forests (Hess et al., 2010; Beckert et al., 2014).

The current state and federal legislations require landowners in southern Brazil to maintain at least $20 \%$ of their rural properties area covered with natural forests, and places severe restrictions on their use. Although this restriction aims to prevent further deforestation, it creates an antagonism between forest protection and the landowner production, so that the regeneration of young Araucaria angustifolia (Brazilian pine) trees and other related species are preferable removed (Diez, 2012). Several landowners use the areas under the forest remnants for livestock grazing or remove seedlings and young trees to avoid their growth. The diversity, stability, and structure of the MOF remnants may be affected by the absence of a reasonable number of seedlings and young trees.

However, absence of intervention does not ensure the conservation of forests, since the tree growth tend to stagnate in its final cycles. It results in a lower natural regeneration index and, according to Sullivan and Sullivan (2016), it does not result in the establishment of structural attributes of primary forests.

Forest interventions are sometimes important and contribute to accelerate the forest succession (Bauhus et al., 2009). Unmanaged natural forests show stable production and growth, decreased diameter at the breast height (DBH) growth over time, low or nonexistent recruitment, competition, limited availability of resources, and high mortality rates, which may indicate a trend of extinction of this species (Beckert et al., 2014).

Therefore, the perpetuity of natural Brazilian pine forests depends on sustainable forest management mechanisms that require better information on their growth rates in different locations. Most of the growth data of commercial tree species used for growth and yield modeling in the tropics are obtained from permanent plots, especially when the forest species have no visible growth rings (Brienen and Zudeima, 2006). The main drawback of these modeling studies is the assumption of a deterministic growth, excluding the natural variability among individual trees, failing to estimate auto correlated growth rates (Brienen and Zudeima, 2006; Skovsgaard and Vanclay, 2008).

Brienen (2005) point out that assumptions and simplifications for growth and yield modeling can lead to unrealistic growth projections, underestimating the actual long-term growth of trees. The use of dendrochronology is an alternative to obtain individual growth rates and evaluate management practices. This is especially used for some tropical species in which the growth rings are visible (Mattos et al., 2011; Speer, 2010).

Information on the growth on the DBH rates is key for a sustainable forest management, allowing the review of historical increments and forecast DBH increments. It also allows the estimation of wood production and calculation of the harvesting time accurately (Skovsgaard and Vanclay, 2008; Braz et al., 2012). Moreover, this information also describes forest competition effects (Curto, 2015), which assists in establish better periods for silvicultural interventions (Santos et al., 2015), periods required for the restoration of the removed forest volume (Braz et al., 2014), forest relationships with the climate, and site index (Mattos et al., 2015), using simple models. These models assume that the forest production and dynamics is an effect of its age, site index and competition.

The objectives of this research were to measure the individual variability of DBH increment of Brazilian pine trees occurring naturally in three different sites in southern Brazil; fit the mean annual increment in $\mathrm{DBH}$ as a function of age and diameter; and evaluate the need of silvicultural intervention based on the accumulated DBH growth curves and current $\mathrm{DBH}$ increment rates, to predict the future diametric structure of Brazilian pine forests.

\section{Results and discussions}

\section{Relationships of DBH increment with age and diameter}

The analysis of covariance for the annual increment in diameter (id) as a function of the diameter $(D B H)$ and age $(t)$ showed a difference between levels ( $\Phi_{0}$ coefficient) and inclination (slope) of regression lines for id (Prob. <0.0001) for each study area (test site), and an interaction between $D B H^{*}$ site and $t^{*}$ site.

The results of the covariate analysis showed a linear effect, suggesting that the growth rates vary according to age $(t)$ and diameter $(D B H)$, with negative correlation between these variables (Table 1 ). According to the analysis of covariance, generating regressions was required for the DBH ratio increment-diameter and $\mathrm{DBH}$ increment-age in separate groups to explain the annual increment in $\mathrm{DBH}$ for each site (Table 1; Fig. 1).

The covariance showed that the DBH growth of Brazilian pine has high variability. This variability can be expressed by different equations for each study site (Fig. 1), indicating that there are differences in the accumulated DBH increment and in their respective slopes. Such differences are probably related to the site index, which combines the most important determinants of tree growth, such as topography, soil characteristics and regional climate (Skovsgaard and Vanclay, 2008). It also showed different forest growth (level) and productive capacity (slope) for each site.

In the equations, the coefficient $\Phi_{0}>0$ showed a less proportional increase of increment with increasing diameter $(D B H)$ and age $(t)$ (Fig. 1). The linear model prediction for the selected individuals indicated that growth was higher in $\mathrm{DBH}$ for young trees and slower for trees reaching maturity. A strong ontogenetic growth pattern was found, with decreasing growth rates with increasing diameter $(D B H)$ and age $(t)$. According to Preztsch and Dieler (2011), this decrease in the growth pattern in larger DBH is a consequence of competition among individuals, featuring a partial symmetry of growth-diameter relationship. According to these authors, this competition limits the use of underground resources such as water and soil nutrients. It also confirms the need of silvicultural interventions for a sustainable forest management of Brazilian pine in southern Brazil. Thus, this species has differences in DBH growth patterns and productive capacity according to the environmental resources available at each site.

The regression models showed decreasing growth rates (growth stagnation) in the last ten years, suggesting a need of silvicultural interventions to maintain the structure of the 
Table 1. Model coefficients and statistical criteria for fit annual DBH increment (id) as a function of $D B H$ and age $(t)$ for the Araucaria angustifolia trees in three selected study areas in Santa Catarina, Brazil.

\begin{tabular}{|c|c|c|c|c|}
\hline \multirow{2}{*}{ Site } & \multicolumn{2}{|c|}{ Coefficients id $(d)$} & \multicolumn{2}{|c|}{ Statistical criteria } \\
\hline & $\Phi_{0}$ & $\Phi_{1}$ & $S_{y x}$ & $R^{2}$ adj \\
\hline SJQ & 0.55406 & $-0.00369 * D B H$ & & \\
\hline URU & 1.44149 & $-0.01295^{*} D B H$ & 0.36 & 0.40 \\
\hline PNL & 1.35450 & $-0.01440 * D B H$ & & \\
\hline \multirow{2}{*}{ Site } & Coefficie & & \multicolumn{2}{|c|}{ Statistical criteria } \\
\hline & $\Phi_{0}$ & $\Phi_{1}$ & $S_{y x}$ & $R^{2}$ adj. \\
\hline SJQ & 0.52180 & $-0.00325 * t$ & \multirow{3}{*}{0.31} & \multirow{3}{*}{0.53} \\
\hline URU & 1.42687 & $-0.02376 * t$ & & \\
\hline PNL & 1.21306 & $-0.01818 * t$ & & \\
\hline
\end{tabular}

$i d$ = annual increase in diameter in $\mathrm{cm} ; \Phi_{0}=$ intercept; $\Phi_{1}=$ angular coefficient; Syx = standard error of the estimate; $\mathrm{R}^{2}$ adj. = Coefficient of determination adjusted; $D B H=$ diameter at breast height; $t=$ age. SJQ = São Joaquim; URU = Urupema; PNL = Painel.
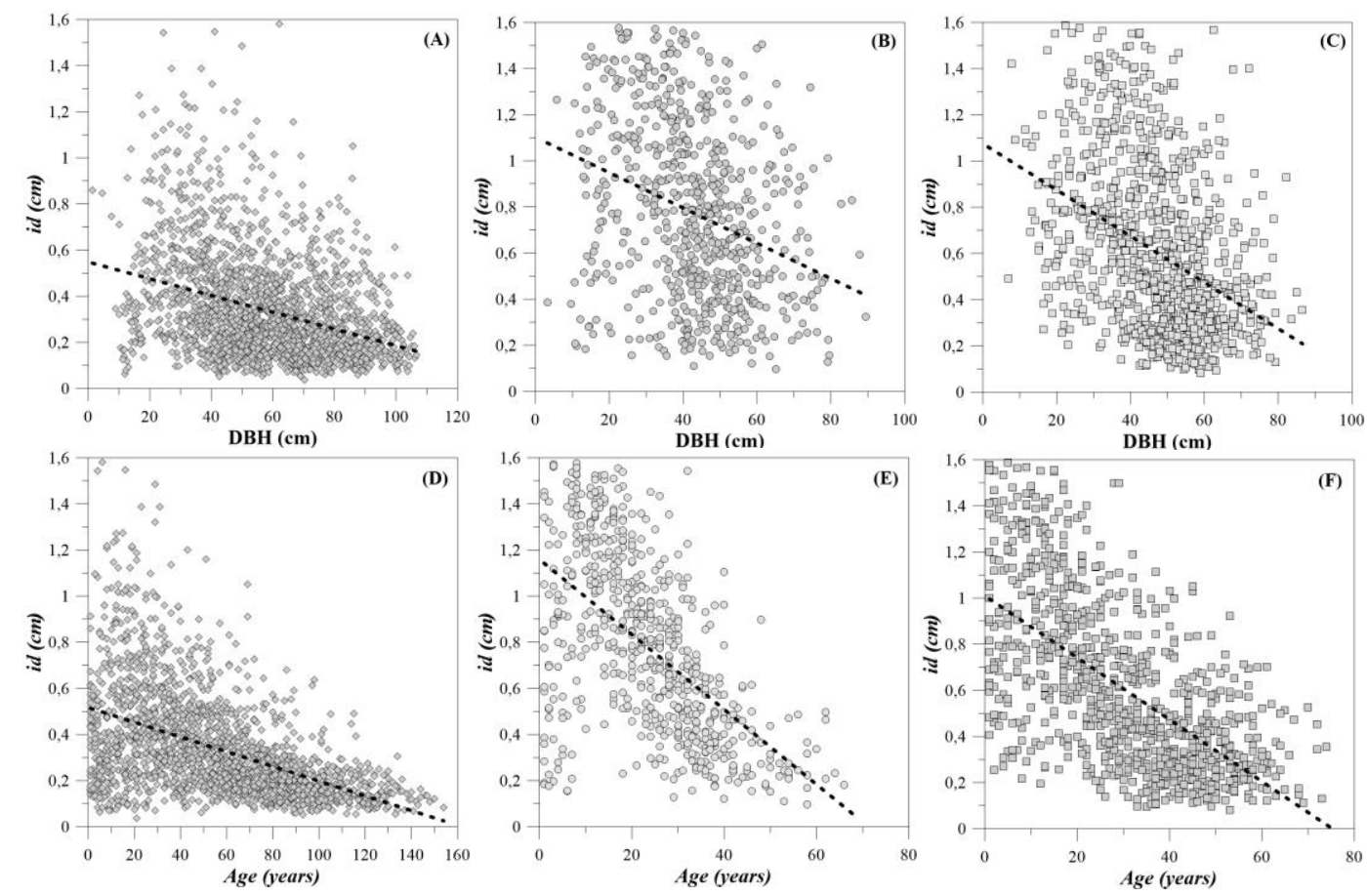

Fig 1. Linear adjustments of increment in diameter with size $(D B H)(A, B$ and $C)$ and age $(t)(D, E$ and $F)$ for Araucaria angustifolia environments in Santa Catarina, Brazil. id = annual increment in diameter; $D B H=$ diameter at the breast height, $t=$ age. Dotted lines indicate the regression lines. Each symbol indicates the increment at a given year. São Joaquim ( $A$ and $D)$, Urupema (B and E), and Painel ( $C$ and $E)$.

Table 2. Increment intervals and average DBH increment of 210 Brazilian pine trees in three selected study areas in Santa Catarina, Brazil.

\begin{tabular}{lccc}
\hline DBH annual growth rates & \multicolumn{2}{c}{ Study Area } \\
\cline { 2 - 3 } & SJQ & PNL & URU \\
\hline Minimum (cm.year ${ }^{-1}$ ) & 0.036 & 0.068 & 0.069 \\
Maximum $\left(\mathrm{cm}_{\text {year }}{ }^{-1}\right)$ & 2.39 & 3.66 & 4.79 \\
Average $\left(\mathrm{cm}\right.$. year $^{-1}$ ) & 0.34 & 0.68 & 0.90 \\
Retrospective analysis (Years) & 60 to 153 & 34 to 68 & 24 to 62 \\
\hline
\end{tabular}

SJQ: São Joaquim; URU: Urupema; PNL: Painel. 

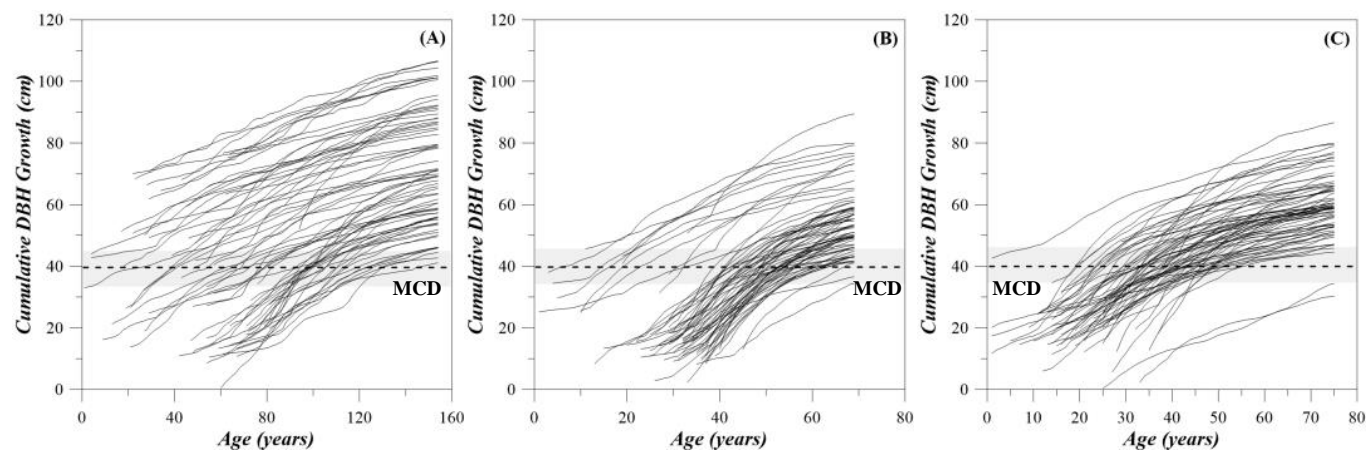

Fig 2. Accumulated diametric growth of Araucaria angustifolia trees in three selected study areas. São Joaquim (A), Urupema (B), Painel (C). Dotted lines indicate the minimum cutting diameter (MCD).

Table 3. Biometric measurements of 210 Araucaria angustifolia (Bertol.) Kuntze trees.

\begin{tabular}{lccc}
\hline Biometric & \multicolumn{3}{c}{ Study Area } \\
\cline { 2 - 4 } measurements & SJQ & PNL & URU \\
\hline Minimum tree height $(\mathrm{m})$ & 12.3 & 12.3 & 11.5 \\
Maximum tree height $(\mathrm{m})$ & 25.1 & 22.6 & 22.8 \\
Average tree height $(\mathrm{m})$ & 18.9 & 18.4 & 16.9 \\
Minimum DBH $(\mathrm{cm})$ & 41.1 & 30.2 & 34.4 \\
Maximum DBH (cm) & 106.6 & 86.6 & 89.4 \\
Average DBH (cm) & 71.5 & 60.2 & 54.8 \\
Sample area (ha) & 4.1 & 4.3 & 2.2 \\
\hline
\end{tabular}

$\mathrm{DBH}=$ diameter at the breast height. SJQ = São Joaquim; URU = Urupema; PNL = Painel

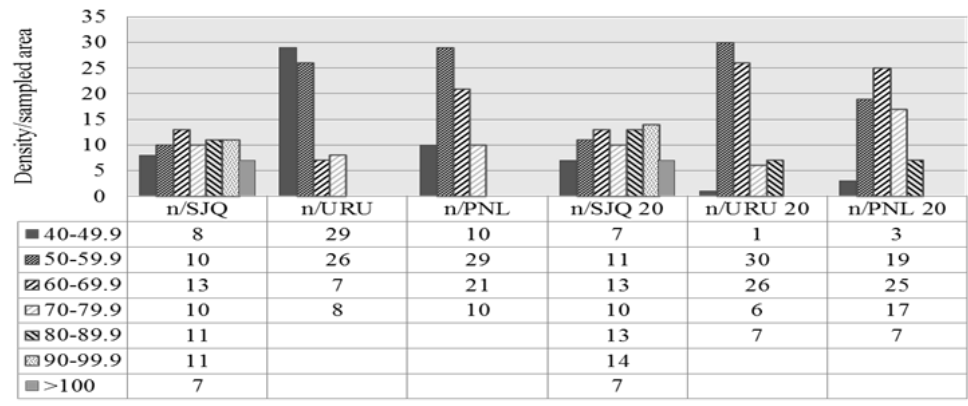

Fig 3. Estimates of the number of Araucaria angustifolia trees by diameter classes based on current rates of diameter at the breast height increment in three study areas in Santa Catarina, Brazil. $n_{1}=$ number of trees of a given diameter class; SJQ = São Joaquim; URU = Urupema; PNL = Painel; $\mathrm{n}_{2}=$ number of trees with the diameter class after 20 years.

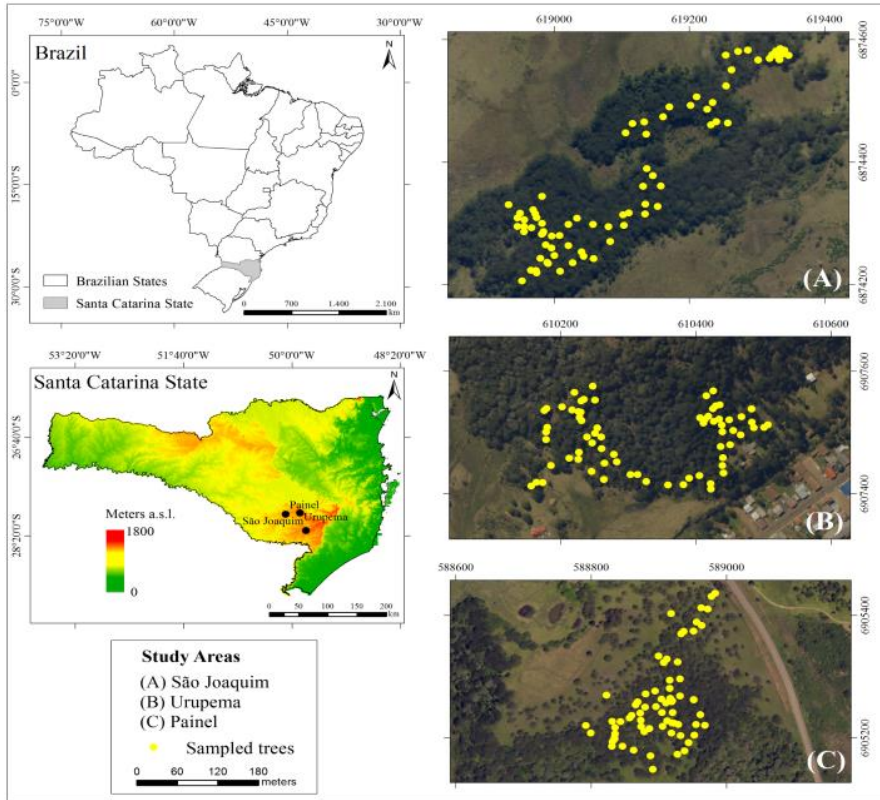

Fig 4. Location of the state of Santa Catarina, Brazil, and the three selected areas used for the dendrochronological studies. Yellow dots indicate the location of the 210 Araucaria angustifolia trees sampled. 
native forests. Brienen and Zudeima (2006) and Rozendaal et al. (2010) pointed out that a forest management allows some trees to be harvested maintaining the natural dynamics of the forest, thus allowing the perpetuation of selected species. Methodologies considering silvicultural interventions have strong application for the Brazilian southern region, in which the Brazilian pine naturally occurs. Moreover, it would encourage landowners to grow Brazilian pine seedlings in their forest remnants, increasing their forest areas, which is currently occupied by pasture and Pinus spp. plantations. This increase in area would allow functional connectivity between isolated forest remnants from different small-scale rural properties.

The lack of silvicultural intervention in the last four decades caused young and intermediate diametrical classes of Brazilian pine trees to compete, reducing their growth potential and prevent them to reach their upper canopy stages, which may compromise the perpetuity of this species and the future of the forest structure. The competition and lack of silvicultural control of tree density may affect the natural dynamics of forests, causing changes in the structure and morphometry of plants, affecting the growth rates and development of new individuals. Medina-Macedo et al. (2016) pointed out that alternatives for conservation of this species must focus on forest remnants located on private properties rather than large conservation units. These authors reported that small forest fragments in southern Brazil that have Brazilian pine can maintain high levels of genetic diversity.

The forest age $(t)$ and the diameter of its trees $(D B H)$ affect the DBH increment. According to Pretzsch (1999), this effect can be described by the growth pattern of an individual tree. This pattern changes from a rapid growth, when the limitation by competition is null, to gradual decreases of vitality due to long-term depositions (Elling 1993), and then to great growth loss (Utschig 1989) or even dieback (Röhle 1987). In other words, the high growth decrease pattern when DBH increment is close to zero may compromise horizontal forest structures, since the trees may have not reached the minimum cutting diameter (MCD). However, low growth rate patterns are site-dependent and subject to considerable variations between sites (Pretzsch 2009).

The diameter-age increase in native forests is usually nonlinear, and affected by several local environmental factors (Pretzsch, 1999). Fig. 1 shows the dependence of the $\mathrm{DBH}$ increment on diameter $(D B H)$ and age $(t)$ when all other environmental variables are constant (Preztsch and Dieler, 2011). The distribution of the relative growth of different diameter $(D B H)$ and age $(t)$ is shown in the slope of the regression lines in Fig. 1. According to this figure, the DBH increment shows a partial symmetry with increasing diameter $(D B H)$ and age $(t)$, in which a stabilization or a stagnant growth pattern is noticed. Therefore, the analyzed bored trees showed that these trees had already reached their growth capacity in DBH (Pretzsch 1999).

\section{Dendrochronology, growth curves, and technical rotation}

The results of the dendrochronological analysis showed a high variability in DBH annual growth rates over time (Table 2). These increments confirm the results found by Mattos et al. (2007) and Hess et al. (2009). The results also present potential for a sustainable forest management of Brazilian pine trees, since this species can achieve relatively rapid large $\mathrm{DBH}$, even with annual variations in increment, and lack of silvicultural interventions in the last 40 years in these three test sites due to the prohibitive legislation. The overall average increase was smaller in SJQ, since this site had a reasonable number of mature trees prior to the prohibitive legislation in the late 1970 s.

The extracted increment rolls showed that the growth rings located near the bark were usually narrower than those closer to the trunk core. Considering the deep limitation of our thread increment borer $(30 \mathrm{~cm})$, some of the sampled trees were most probably over 200 years old. Trees in SJQ showed greater age and large DBH than those in URU and PNL. The individual DBH growth $(40$ to $100 \mathrm{~cm})$ is shown in Fig. 2.

The age inflection and growth stagnation of the sampled Brazilian pine trees occurred when they were 35 to 45 years old. This time interval is usually related to the age of biological rotation in DBH (Hess et al., 2009). Generally, all DBH classes were stabilized, since reduced growth rates are noticed when trees reached their maximum support capacity, also known as law of diminishing returns. The expected DBH increment was smaller over time even with all available environmental resources (Rodriguez, 1991). According to Pretzsch (2009), the variation in growth inflection represents the different conditions in which each tree has grown, since intraspecific and interspecific competition, space, and availability of resources affect their development.

According to the analysis of the rings closer to the trunk core, the DBH increment was greater in the first years, despite ecological variations regarding site and climate differences. The large increments were found close and prior to the period of logging prohibition established in the late 1970s (Goulart Filho, 2002, Silveira 2005). The Brazilian pine increased more than $1.0 \mathrm{~cm}$ year $^{-1}$ at early stages, despite the negative correlation in DBH increment (negative coefficient $\Phi_{1}$ ). This increment allowed the trees to reach favorable growing conditions, reaching a MCD in 40 years. The monitoring of the growth rings of Brazilian pine trees showed the variation over their life cycle (Lopez et al., 2013), and proper DBH rates for adequate silvicultural interventions. The analysis of growth rings of trees is important to assess the increment history, which is expected to be similar to their future growth. The stability of the population size and distribution over the time, and regeneration is expected to be continuous and not erratic (Brienen and Zudeima, 2006).

The DBH increasing rates shown in Fig. 2 indicate that the Brazilian pine trees had an optimum harvesting diameter, with $M C D$ of $40 \mathrm{~cm}$. The time interval in which these trees can achieve this MCD is between 25 to 112 years, varying according to the study area, competition, and due to nonintervention in the forest. This range of age shows the growth rate variability of the Brazilian pine. However, suitable management mechanisms in selected sites with good site index may result in a fast achievement of this MCD. Therefore, a proper historical characterization of the DBH increment of each site must be considered when proposing a sustainable forest management protocol.

The average DBH increment in SJQ within the inflection period of the growth curve (45 years) was $0.51 \mathrm{~cm}_{\text {year }}{ }^{-1}$, and $0.15 \mathrm{~cm}$ year $^{-1}$ for the last 10 years (stagnation of the 
inflection curve). This result shows a decrease of $71 \%$ in the $\mathrm{DBH}$ increment rate. The DBH growth in the inflection period (35 years) in URU was $0.96 \mathrm{~cm}$ year $^{-1}$, and in PNL was 0.89 $\mathrm{cm}$ year ${ }^{-1}$; and for the last 10 years, it was $0.49 \mathrm{~cm}_{\text {year }}{ }^{-1}$ (URU) and $0.34 \mathrm{~cm}$ year $^{-1}$ (PNL), representing a reduction of $49 \%$ (URU) and $62 \%$ (PNL). The DBH increment rate, including all sites and the entire period evaluated, was 0.78 $\mathrm{cm}$ year $^{-1}$, and $0.33 \mathrm{~cm}$ year ${ }^{-1}$ for the last 10 years, representing a reduction of $58 \%$. Thus, a single tree with an average DBH growth rate of $0.78 \mathrm{~cm}_{\text {year }}{ }^{-1}$ would need 51 years to achieve the MCD of $40 \mathrm{~cm}$.

The dendrochronological growth curve in Fig. 2 shows that trees with larger DBH require more time to reach upper diametric class intervals. Therefore, forest management is needed for individuals of lower and intermediate DBH classes to achieve more rapidly their maximum growth potential. Considering proper forest management practices and a minimum DBH increment rate of $1.0 \mathrm{~cm}_{\text {year }}{ }^{-1}$, a tree would require 40 years to reach a MCD of $40 \mathrm{~cm}$.

According to Brienen and Zudeima (2006), monitoring native forests with frequent measurements of $D B H$ is needed. These measurements allow a better information on DBH increments, however, the exact time that a given forest will reach maturity cannot be forecasted due to the lack of recruitment and mortality rates of Brazilian pine trees. The forecast of DBH of the different diameter class intervals, considering the average rates of the DBH increment of each study area, for the last ten years are shown in Fig. 3.

Even with the low DBH growth rates found in the last 20 years, some trees migrated to upper diametric class intervals. However, this increase is smaller than the potential that this species must reach half of the MCD, since the increase in DBH reduces the growth rates. Therefore, silvicultural interventions in selected Brazilian pine trees may provide some profitability for local communities, and help the conservation of this endangered species. PorterBolland et al. (2012) analyzed 40 protected areas and 33 forest communities in 16 countries -11 in Latin America, three in Africa and two in Asia - and found that protected areas lost about $1.47 \%$ of vegetation cover per year, while forests that are managed by communities had a loss of about $0.24 \%$ per year.

Based on DBH increment estimates in the three selected study areas $\left(0.78\right.$ to $\left.>1.00 \mathrm{~cm}_{\text {year }}{ }^{-1}\right)$, the period between two silvicultural interventions will be 20 to 26 years, considering that the remaining trees with diameter of \pm 20 $\mathrm{cm}$ can reach the MCD of $40 \mathrm{~cm}$ in the next cutting cycle. The results showed that most of the trees reached the MCD, showing inflection in the accumulated growth curve. Lacerda (2016) suggested that such characteristics are very similar to old-growth forests, which show very low DBH growth rates and do not have the diversity levels expected, indicating that young trees may not reach upper DBH classes anymore. The extraction of selected $A$. angustifolia trees through sustainable forest management would reduce the basal area and canopy coverage of forest remnants. Contrastingly, this reduction would lead to less competition between trees and allow young Brazilian pine trees to reach the MCD. The current state and federal legislations, from the local landowners' point of view, hinders the regeneration and development of young trees, which may compromise the future of these forest structures.

\section{Materials and Methods}

\section{Study design}

The study was conducted in three natural forest areas of Brazilian pine in southern Brazil, São Joaquim (SJQ), Urupema (URU) and Painel (PNL) (Fig. 4). The typology of these forests is Mixed Ombrophilous Forest, with Brazilian pine as predominant species in the dominant canopy strata. The region has climate $\mathrm{Cfb}$, according to the Köppen classification, constantly humid temperate, with summer without dry season; annual average temperature of 13.8 to $15.8^{\circ} \mathrm{C}$; total annual rainfall of 1,360 to $1,600 \mathrm{~mm}$, evenly distributed throughout the year; and relative humidity of $80 \%$ to $83 \%$ (Epagri, 2002).

Seventy Brazilian pine trees were selected in each area, totaling 210 trees (Table 3), and a total of 14,151 chronological series of DBH increment were evaluated. The trees were selected according to a minimum cutting diameter (MCD) of $40 \mathrm{~cm}$. The location of the trees was assessed by a handheld GPS (Garmin II). Each tree had its diameter at breast height (DBH) and total height measured. Two increment rolls from each tree were extracted perpendicularly to the diameter breast height (DBH) with a thread increment borer of $30 \mathrm{~cm}$ (Pressler Sounder) (Assmann, 1970). The increment cores were carefully sanded and their rings were marked. The ages were assessed by counting the rings. The width of the rings was measured, and the annual increment in DBH was assessed using a digital measuring device (Lintab-6) which has accuracy of $0.0001 \mathrm{~mm}$ and is supported by a software for time series analysis and presentation (TSAP-Win) (Schöngart et al., 2005).

\section{Statistical analysis}

Data analysis was performed using the Time Series Analysis Program (TSAP-Win) with cross-dating procedure (Rinn Tech, 2010). The increment data were subjected to analysis of covariance to test whether the slopes and levels differ significantly between the study areas (Kaps and Lamberson, 2004), i.e., the differences in growth patterns and productive capacity.

The increment in DBH and its variability was considered a dependent variable that explains aspects of the site index (Schneider et al., 2009). Contrastingly, the DBH and age were considered continuous independent variables. The applied model proposed by Kaps and Lamberson (2004), including the group effect and simple linear regression is shown in Eq. 1.

$y_{i j}=\beta_{0}+\tau_{i}+\beta_{1} x_{i j}+\sum_{i} \beta_{2 i}(\tau * x)_{i j}+\varepsilon_{i j,} i=1, \ldots, a ; j=$

$1, \ldots, \mathrm{n} ; \quad$ Eq. 1

Wherein; $y_{i j}$ is the observation $j$ in the group $i ; \tau_{i}$ is the effect of the group $i ; \beta_{0}, \beta_{1}$ and $\beta_{2 i}$ is the regression parameters; $x_{i j}$ is the value of the continuous independent variable for observation $\mathrm{j}$ in the group $\left.\mathrm{i} ; \tau^{*} \mathrm{x}\right) \mathrm{ij}$ is the interaction groupcovariate; and $\varepsilon_{\mathrm{ij}}$ is the random error.

The average annual increment in $\mathrm{DBH}$ (id) for each tree was fitted to the diameter (DBH) and age $(t)$ according to the equations 2 and 3. 
$i d=\Phi_{0}+\Phi_{1} * D B H$

Eq. 2

$i d=\Phi_{0}+\Phi_{1} * t$

Eq. 3

All data analysis was performed using the SAS 9.3 software (Statistic Analysis System) (SAS Institute Inc., 2012). The model residuals did not show any violation of the regression conditions (normality, and homogeneity of variance). The growth curves were developed after the cross-dating analysis, and the age of biological rotation in DBH for forest management was obtained. Differences in cumulative diameter growth rate were assessed by calculating the DBH average, minimum and maximum of selected intervals. The cumulative diameter growth curves were developed using the measured values acquired with the thread increment borer.

The diameter forecasting for 20 years was carried out by adding the average increment in $\mathrm{DBH}$ from the last ten years (imd10). The weighted average was added for the selected DBH class intervals for each site. The number of trees with a certain DBH class interval after 20 years $\left(\operatorname{ncd}_{120}\right)$ was calculated by adding the number of remaining trees in the class $\left(\mathrm{ncd}_{\mathrm{ir}}\right)$ and the number of trees that had migrated from the previous class interval $\left(\mathrm{ncd}_{\mathrm{im}}\right)$ (equation 4 );

$\operatorname{ncd}_{\mathrm{i} 20}=\mathrm{ncd}_{\mathrm{ir}}+\mathrm{ncd}_{\mathrm{im}}$

Eq. 4

While, the number of trees of the former class comprised trees that did not migrate to next classes.

\section{Conclusion}

The results found in the study (variability analysis of the annual increment in $\mathrm{DBH}$, fit functions of the increment in time, growth form and increment rate) show a clear need of silvicultural interventions. Under current conditions, without applying any forest management practice, there is a risk in maintaining and forming the future diametric structure of the Araucaria Forests. The results also confirmed that the restrictive legislation is not sufficient to ensure the conservation of this endangered species. This is due to the decrease and stagnation of the growth rates in DBH noticed in all selected study areas. The accumulated growth curves in DBH can be used to assess the biological rotation point of this species. Planned interventions in natural forest remnants can result in better growth rates, natural regeneration, and conservation of species.

\section{Acknowledgements}

The first author is supported by the National Council for Scientific and Technological Development (CNPq) (Process 482542/2013-6). The authors thank the Foundation of the Santa Catarina State Research (FAPESC). Special thanks to the local landowners who allowed data collection in their rural properties.

\section{References}

Assmann E (1970) The principles of forest yield study. Oxford: Pergamon Press. 506p.

Bauhus J, Puetman K, Messier C (2009) Silviculture for oldgrowth attributes. For Ecol Manag. (258):525-537.
Beckert SM, Rosot MAD, Rosot NC (2014) Crescimento e dinâmica de Araucaria angustifolia (Bert.) O. Ktze. em fragmento de Floresta Ombrófila Mista. Sci For. 42(102): 209-218.

Braz EM, Thaines F, Mattos PP, Oliveira LC, Ribas LA, Oliveira MVND, Thaines AAR (2014). Management of Amburana cearensis var. acreana in Acre state, Brazil. Cienc Florest. 24:455-463.

Braz EM, Schneider PR, Mattos PP, Selle GL, Thaines F, Ribas LA, Vuaden E (2012) Taxa de corte sustentável para manejo das florestas tropicais. Cienc Florest. 22(1):137145.

Brienen RJW (2005) Tree rings in the tropics; a study on growth and ages of Bolivian rain forest trees. PhD thesis, Utrecht University, PROMAB scientific series 10, $144 \mathrm{f}$.

Brienen RJW, Zuidema PA (2006) The use of tree rings in tropical forest management: projecting timber yields of four Bolivian tree species. For. Ecol. Manag. 226:256-267.

Curto RA (2015) Avaliação do crescimento e potencial de manejo em plantio superestocado de Araucaria angustifolia (Bert.) O. Ktze. PhD thesis. $250 f$.

Diez JJ (2012) Sustainable forest management-case studies. Accessed september 30, 2015. Disponível em: http://www.intechopen.com/books/sustainable-forestmanagement-case-studies.

Elling W (1993) Immissionen im ursachenkomplex von tannenschädigung und tannensterben. Allg Forstztg. 48(2):87-95.

Epagri (2002) Dados e informações biofísicas da unidade de planejamento regional planalto sul catarinense - UPR 3 , Florianópolis: EPAGRI/CIRAM, 70p.

Gibbs HK, Brown S, Nilesand JO, Foley JA (2007) Monitoring and estimating tropical forest carbon stocks: making REDD a reality. Environm Res Lett. 2(4):1-13.

Hess AF, Minatti M, Ferrari L, Pintro BA (2014) Manejo de floresta ombrófila mista pelo método de Liocourt, Município de Painel, SC. Cerne 20(4):575-580.

Hess AF, Calgarotto AR, Pinheiro R, Wanginiak TCR (2010) Proposta de manejo de Araucaria angustifolia utilizando o quociente de Liocourt e análise de incremento, em propriedade rural no município de Lages, SC. Pesq Florest Brasil. 30(64):337-345.

Hess AF, Schneider PR, Finger, CAG (2009) Crescimento em diâmetro de Araucaria angustifolia (Bertol.) Kuntze em função da idade, em três regiões do Rio Grande do Sul. Cienc Florest. 19(1):7-22.

Filho AG (2002) Formação econômica de Santa Catarina. Cidade Futura. 25p.

Kaps M, Lamberson WR (2004) Biostatistics for animal science. CABI Publishing, London, UK. 445p.

Klein RM (1978) Mapa fitogeográfico do Estado de Santa Catarina. In: Reitz R (ed) Flora ilustrada catarinense. Itajaí. Herbário Barbosa Rodrigues. 24p.

Lacerda, AEB (2016) Conservation strategies for araucaria forests in southern Brazil: assessing current and alternative approaches. Biotropica. 48(4):537-544.

López L, Villalba R, Bravo F (2013) Cumulative diameter growth and biological rotation age for seven tree species in the Cerrado biogeographical province of Bolivia. For Ecol Manag. 292:49-55.

Mattos PP, Braz EM, Domene VD, Sampaio EVSB, Gasson P, Pareyn FGC, Alvarez IA, Baracat A, Araújo EL (2015) 
Climate-tree growth relationships of Mimosa tenuiflora in seasonally dry tropical forest, Brazil. Cerne 21(1):141-149.

Mattos PP, Braz EM, Hess AF, Salis SM (2011) A dendrocronologia e o manejo florestal sustentável em florestas tropicais. Colombo: Embrapa Florestas; Corumbá: Embrapa Pantanal. (Embrapa Florestas. Documentos, 218); (Embrapa Pantanal. Documentos, 112) 37p.

Mattos PP, Santos AT, Rivera H, Oliveira YMM, Rosot MAD, Garrastazu MC (2007) Crescimento de Araucaria angustifolia na Reserva Florestal Embrapa/Epagri, Caçador, SC. Pesq Florest Brasil. 55(1):107-114.

Medina-Macedo L, Lacerda AEB, Sebbenn AM, Ribeiro JZ, Soccold CR, Bittencourt JVM (2016) Using genetic diversity and mating system parameters estimated from genetic markers to determine strategies for the conservation of Araucaria angustifolia (Bert.) O. Kuntze (Araucariaceae). Conserv Genet. 17(2):413-423.

Moya J, Lara A (2011) Cronologías de ancho de anillos de queñoa (Polylepis tarapacana) para los últimos 500 años en el Altiplano de la región de Arica y Parinacota, Chile. Bosque, 32(2):165-173.

Oliveira JM, Santarosa E, Pillar VD, Roig FA (2009) Seasonal cambium activity in the subtropical rain forest tree Araucaria angustifolia. Trees 23(1):107-115.

Nascimento ATR, Longhi SJ, Brena DA (2001) Estrutura e padrões de distribuição espacial de espécies arbóreas em uma amostra de Floresta Ombrófila Mista em Nova Prata, RS. Cienc Florest. 11(1):105-119.

Porter-Bolland L, Ellis EA, Guariguata MR, Ruiz-Mallén I, Negrete-Yankelevich S, Reyes-García V (2012) Community managed forests and forest protected areas: an assessment of their conservation effectiveness across the tropics. For Ecol Manag. 268(1):6-17.

Pretzsch H (1999) Waldwachstum im Wandel, Konsequenzen für Forstwissenschaft und Forstwirtschaft. Forstwiss Centralbl. 118(1):228-250.

Pretzsch H (2009) Forest dynamics, growth and yield. From measurement to model. Springer, Berlin $664 \mathrm{p}$.

Pretzsch H, Dieler J (2011) The dependency of the sizegrowth relationship of Norway spruce (Picea abies [L.] Karst.) and European beech (Fagus sylvatica [L.]) in forest stands on long-term site conditions, drought events, and ozone stress. Trees. 25(3):355-369.

Ribeiro MC, Metzger JP, Martensen AC, Ponzoni F, Hirota MM (2009) Brazilian atlantic forest: how much is left and how is the remaining forest distributed? Implications for conservation. Biol Conserv. 142(6):1141-1153.

Rinn Tech (2010) TSAP-WIN: Time series analysis and presentation dendrochonology and related applications.
Rodriguez LCE (1991) Gerenciamento da produção florestal documentos florestais 13:1-41.

Röhle H (1987) Entwicklung von Vitalität, Zuwachs und Biomassenstruktur der Fichte in verschiedenen bayerischen Untersuchungsgebieten unter dem Einflub der neuartigen Walderkrankungen. Forstliche Forschungsberichte München. 83:1-122.

Rozendaal DMA, Gamboa CCS, Zudeima PA (2010) Timber yield projections for tropical tree species: the influence of fast juvenile growth on timber volume recovery. For Ecol Manag. 259:2292-2300.

Santos AT, Mattos PP, Braz EM, Rosot NC (2015) Determinação da época de desbaste pela análise dendrocronológica e morfométrica de Ocotea porosa (Nees \& Mart.) Barroso em povoamento não manejado. Cienc Florest. 25(3):699-709.

SAS Institute Inc. 2012. SAS/ETS ${ }^{\circledR} 12.1$ User's Guide. Cary, NC: SAS Institute Inc. 3424p.

Silveira CR (2005) História da indústria da madeira: serra catarinense, 1940-2005. Lages, SC, 425p.

Schöngart J, Piedade MTF, Wittmann F, Junk WJ, Worbes M (2005) Wood growth patterns of Macrolobium acaciifolium (Benth.) Benth. (Fabaceae) in Amazonian black-water and white-water floodplain forests. Oecologia 145(3):654-661.

Schneider PR, Schneider PSP, Souza CAM (2009) Análise de regressão aplicada à engenharia florestal. FACOS, Santa Maria. 249p.

Skovsgaard JP, Vanclay JK (2008) Forest site productivity: a review of the evolution of dendrometric concepts for even-aged stands. Forestry 81:13-31.

Speer J (2010) Fundamentals of tree-ring research. The University of Arizona Press, Tucson, UEA.

Stefenon VM, O Gailing, R Finkeldey (2008) Genetic structure and the conservation of genetic resources of Brazilian pine (Araucaria angustifolia). For Ecol Manag. 255:2718-2725.

Sullivan TP, Sullivan DS (2016) Acceleration of old-growth structural attributes in lodgepole pine forest: Tree growth and stand structure 25 years after thinning. For Ecol Manag. 365:96-106.

Utschig H (1989) Waldwachstumskundliche Untersuchungen im Zusammenhang mit Waldschäden. Auswertung der Zuwachstrendanalyseflächen des Lehrstuhles für Waldwachstumskunde für die Fichte (Picea abies (L.) Karst.) in Bayern. Forstliche Forschungsberichte München 97:198p. 